\title{
Antibacterial Activity of Pollen Extracts on Pathogenic Microflora from Milk
}

\author{
Liviu Al. MĂRGHITAȘ ${ }^{1}$, Claudia PAȘCA ${ }^{1 *}$, Daniel S. DEZMIREAN ${ }^{1}$, Otilia BOBIȘ ${ }^{1}$, Victorița BONTA ${ }^{1}$, Rodica \\ Mărgăoan ${ }^{2}$, Floare CHIRILA $\breve{3}^{3}$ and Nicodim FIȚ ${ }^{3}$ \\ ${ }^{1}$ Department of Apiculture and Sericiculture: University of Agricultural Sciences and Veterinary \\ Medicine, România \\ ${ }^{2}$ Department of Horticulture, Micropropagation: University of Agricultural Sciences and Veterinary \\ Medicine, România \\ ${ }^{3}$ Department of Microbiology (Veterinary Medicine): University of Agricultural Sciences and Veterinary \\ Medicine, România \\ * corresponding author: claudia.pasca@usamvcluj.ro
}

Bulletin UASVM Animal Science and Biotechnologies 73(2)/ 2016

Print ISSN 1843-5262; Electronic ISSN 1843-536X

DOI:10.15835/buasvmcn-asb: 12296

\begin{abstract}
Bee-pollen was used for thousands of years as functional food and medicinal plant product. Various beneficial effects were attributed to it and its consumption was increased years. The tests have been made on 16 pollen samples of the following families: Rosaceae, Salicaceae, Fabaceae, Tiliaceae, Asteraceae, Brassicaceae and two polifloral pollen assortment, using difuzimetric method. Among the tested bacteria, the Onobrychis viciifolia pollen has the highest sensitivity $11.86 \pm 1.79 \mathrm{~mm}$ and the low antibacterial activity is for Brassica sp. pollen $8.65 \pm 2.65$ $\mathrm{mm}$.The use of antibiotic substances over a long period of time resulted in larger doses of residues in milk, representing a potential biohazard. The conclusion from this study is that the use of ethanol extracts of pollen is a real alternative in the treatment of cow with various diseases.
\end{abstract}

Keywords: antibacterial activity, strains, pollen extracts

\section{INTRODUCTION}

The honeybee (Apis mellifera) makes various bee products from plants, flower nectar and flower pollen. Bee pollen is rich in carbohydrates, crude fibers, lipids, vitamins and phenolic compounds, being commonly named as the "perfectly complete food", due to the presence of all the essential amino acids (Marivalda et al., 2015).

Katarína et al. (2015), Pascoal et al. (2014), found that bee pollen is a healthy food with a wide range of therapeutic properties such as antimicrobial being Gram-positive bacteria the most sensitive, antifungal, antioxidant, antiradiation, hepatoprotective, chemoprotective and/or chemopreventive and anti-inflammatory benefits.

\section{AIMS AND OBJECTIVES}

The aim of our study is to assess the antibacterial activity of some pollen extracts over bacteria in milk as an alternative to current antibiotic treatments.

\section{MATERIALS AND METHODS}

For the experiment the preparation of alcoholic extracts from pollen (Crataegus monogyna, Salix sp., Prunus sp., Multifloral bee pollen, Amorpha fruticosa, Tilia sp., Rosa canina, Taraxacum sp., Crataegus monogyna, Brassica sp., Onobrychis viciifolia) $2 \mathrm{~g}$ milled and homogenized pollen were extracted using $15 \mathrm{ml}$ of ethanol:water solution (70:30, v:v).

The antibacterial activity was assessed by difuzimetric method (similar to antibiogram), and calculating the minimum inhibitory concentration for the pollen extracts against the isolated microorganisms of patogenic milk from cows with clinical mastitis (Pașca et al., 2015), using 10 strains belonging to Staphylococcus genera. 
Tab. 1. Results of the test for the determination of the susceptibility of bee pollen extracts ( $\mathrm{mm}$, zone of inhibition)

\begin{tabular}{|c|c|c|c|c|c|c|c|c|c|c|}
\hline \multirow[b]{2}{*}{ Pollen species } & \multicolumn{3}{|c|}{ Staphylococcus xylosus } & \multicolumn{2}{|c|}{$\begin{array}{l}\text { Staphylococcus } \\
\text { hominis }\end{array}$} & \multirow{2}{*}{$\begin{array}{c}\text { Staph. } \\
\text { chromogenes } \\
\text { Strain } \\
1\end{array}$} & \multicolumn{4}{|c|}{ Staphylococcus intermedius } \\
\hline & $\begin{array}{l}\text { Strain } \\
\quad 1\end{array}$ & $\begin{array}{l}\text { Strain } \\
2\end{array}$ & Strain 3 & $\begin{array}{l}\text { Strain } \\
1\end{array}$ & Strain 2 & & $\begin{array}{l}\text { Strain } \\
\quad 1\end{array}$ & $\begin{array}{l}\text { Strain } \\
\quad 2\end{array}$ & Strain 3 & $\begin{array}{c}\text { Strain } \\
4\end{array}$ \\
\hline $\begin{array}{l}\text { Crataegus } \\
\text { monogyna }\end{array}$ & 11.00 & 15.33 & 9.17 & 11.00 & 7.67 & 10.00 & 9.00 & 6.83 & 8.00 & 9.50 \\
\hline Salix sp. & 13.33 & 12.33 & 10.33 & 9.33 & 7.50 & 8.00 & 8.67 & 8.83 & 8.00 & 9.17 \\
\hline Prunus sp. & 8.17 & 11.00 & 9.67 & 10.33 & 7.33 & 10.17 & 8.83 & 8.33 & 9.67 & 7.50 \\
\hline $\begin{array}{l}\text { Multifloral bee } \\
\text { pollen }\end{array}$ & 8.83 & 12.00 & 10.67 & 10.67 & 7.00 & 9.33 & 8.67 & 9.67 & 9.33 & 9.17 \\
\hline $\begin{array}{l}\text { Multifloral bee } \\
\text { pollen }\end{array}$ & 9.83 & 11.00 & 11.33 & 8.33 & 7.50 & 10.33 & 9.83 & 8.17 & 8.67 & 9.00 \\
\hline $\begin{array}{l}\text { Amorpha } \\
\text { fruticosa }\end{array}$ & 8.67 & 11.67 & 8.33 & 10.67 & 7.00 & 10.00 & 9.00 & 7.00 & 8.67 & 8.50 \\
\hline $\begin{array}{l}\text { Prunus sp.; } \\
\text { Salix sp. }\end{array}$ & 10.17 & 10.67 & 13.33 & 10.33 & 8.00 & 8.67 & 8.67 & 7.50 & 8.00 & 9.00 \\
\hline Prunus sp. & 11.83 & 11.00 & 9.33 & 9.33 & 8.00 & 10.00 & 8.83 & 8.67 & 9.33 & 10.33 \\
\hline Tilia sp. & 11.00 & 9.00 & 10.00 & 10.67 & 7.83 & 8.33 & 8.67 & 7.67 & 8.50 & 8.67 \\
\hline Rosa canina & 8.33 & 11.17 & 11.00 & 9.00 & 7.33 & 8.00 & 9.67 & 8.67 & 9.00 & 7.33 \\
\hline $\begin{array}{l}\text { Taraxacum sp.; } \\
\text { Salix sp. }\end{array}$ & 12.33 & 8.67 & 10.00 & 10.33 & 8.67 & 7.00 & 9.67 & 9.17 & 7.83 & 10.00 \\
\hline Brassica sp. & 9.67 & 8.00 & 10.33 & 8.83 & 7.50 & 9.33 & 9.50 & 7.50 & 7.67 & 8.65 \\
\hline $\begin{array}{l}\text { Crataegus } \\
\text { monogyna }\end{array}$ & 15.33 & 10.17 & 13.00 & 9.00 & 9.50 & 9.67 & 11.00 & 67 & 9.33 & 8.67 \\
\hline $\begin{array}{c}\text { Crataegus } \\
\text { monogyna }\end{array}$ & 16.33 & 15.33 & 10.67 & 8.33 & 7.67 & 8.00 & 10.67 & 8.33 & 6.00 & 7.83 \\
\hline Salix sp. & 16.00 & 11.33 & 10.67 & 10.00 & 7.67 & 7.67 & 14.33 & 13.00 & 8.00 & 8.67 \\
\hline $\begin{array}{l}\text { Onobrychis } \\
\text { viciifolia }\end{array}$ & 14.13 & 13.00 & 14.33 & 12.50 & 6.80 & 17.33 & 10.17 & 11.00 & 10.33 & 9.00 \\
\hline
\end{tabular}

\section{RESULTS AND DISCUSSION}

Among the tested bacteria, the Onobrychis viciifolia pollen has the highest sensitivity $11.86 \pm 1.79 \mathrm{~mm}$ and the low antibacterial activity is for Brassica sp. pollen $8.65 \pm 2.65 \mathrm{~mm}$ (Table 1.)

\section{CONCLUSION}

The results of the present investigation revealed that bee pollen extracts could be useful in the prevention of diseases in which Staphylococcus ssp. are implicated.

Using ethanol extracts of Onobrychis viciifolia in the treatment of cow's mastitis with positive impact could reducing contaminants in milk and emergence of antibiotic resistance.

\section{REFERENCES}

1. Marivalda SB, Machado CS, Sodré GS, Dias LG, Estevinho Leticia M and de Carvalho CAL (2015). Microbiological Assessment, Nutritional Characterization and Phenolic Compounds of Bee Pollen from Mellipona mandacaia Smith, 1983. Molecules 20(7):12525-12544.

2. Katarína FŠ, Nôžková J, Máriássyová M, Kačániová M (2016). Biologically active antimicrobial and antioxidant substances in the Helianthus annuus L. bee pollen. Journal of environmental science and health 51(3):176-181.

3. Pascoal A, Rodrigues S, Teixeira A, Feás X, Estevinho LM (2014). Biological activities of commercial bee pollens: Antimicrobial, antimutagenic, antioxidant and antiinflammatory. Food and Chemical Toxicology 63:233-239.

4. Paşca C, Mărghitaş LA, Dezmirean D, Bobiş O, Bonta V, Mărgăoan R, Chirilă F, Fit N (2015). The assessment of the antibacterial activity of some plant extracts on normal and pathogenic microflora from milk. Scientific Papers: Animal Science and Biotechnologies, 48 (1). 